\title{
Prices of Apartments in Relation to Noise Level in
}

\section{Poland}

\author{
Kinga Szopińska and Małgorzata Krajewska \\ Department of Geomatics, Geodesy and Spatial Economy, University of Technology and Life Sciences, Bydgoszcz 85-225, Poland
}

\begin{abstract}
Acoustic climate of a given area ought to be a factor of considerable significance in investment processes in an urbanized area, especially in a residential real estate market, due to its extensive influence on the living standards of its inhabitants. In the following article, the authors have given an analysis of the residential market of housing units located in areas of acceptable and excessive noise levels in preselected regions of Poland. With this end in view, an entirely new source of information has been used in the research - an acoustic map which has been defined and applied to produce the outcome of the analysis. It allowed for the recognition of whether or not the noise level influences decisions made by investors existing in a local residential real estate market.
\end{abstract}

Key words: Acoustic climate, noise strategic map, residential real estate.

\section{Introduction}

Noise is defined as any undesirable, disturbing and harmful sounds causing environmental discomfort. Produced by sources of various kinds, it contributes to the creation of acoustic climate of the environment, in other words an assembly of acoustic phenomena in a given area [1]. Noise sensitivity is a subjective term depends upon predispositions of a person as well as sound characteristics. Thus, certain sounds may in the same time cause pleasant sensations or be disturbing depending on a recipient. Acoustic climate existing in a given area should be a major factor taken into consideration in an investment process of an urbanized area due to its significant contribution to inhabitants' quality of life, especially regarding residential real estate [2].

Residential properties, as goods satisfying basic needs of a man (such as sleeping, eating, relaxation, family life, studying, housework etc.), have been categorized in Poland into: detached houses, semi-detached and terraced houses, tenement houses,

Corresponding author: Kinga Szopińska, Ph.D. student, research fields: environment engineering, real estate management and protection of urban areas from noise. E-mail: k.szopinska@utp.edu.pl. apartments in residential buildings (including commercial and residential premises as well as cooperative member's ownership right for residential premises) [3]. Residential real estate in Poland is a consumer market (consumers buy for themselves) to the greater extend and only relatively small part of it is an investment market (apartments for rent) [4-6], which would particularly indicate a significant role of environmental factors while making investment decisions. Due to the fact that housing resources mainly consist of multi-family residential buildings — approximately 67\% [7] apartment market which is regarded the most developed one, was the subject of the analysis.

Assuming that transaction prices of properties reflect their characteristics, an attempt to answer the question whether the acoustic climate of the surroundings of a selected research area of Poland influences the residential real estate market has been made. The second objective of this paper is to present the extensive use of acoustic maps not only to evaluate the noise level but also as a base for comparative analysis. Therefore the spatial analyses were performed with the use of NSM (noise strategic map), the latest (the first acoustic maps in Poland 
were created in the years 2005-2006), professional source of information concerning the surrounding space.

\section{Acoustic Map}

Directive 2002/49/EC of the European Parliament and of the Council of 25 June 2002 relating to the assessment and management of environmental is the major legal act regulating the problem of noise protection which aims at unifying procedures related to estimating the level of environment's exposure to noise within the member states. According to the directive, NSM is an averaged map of noise generated into environment by various groups of sources, which enables holistic evaluation of a level of noise exposure within an urban area, provides the possibility to determine the origins of such phenomena as well as the opportunity to prepare general prognoses of alterations of its levels. It is the responsibility of state members of European Community to restrict the level of noise in the areas where its harmful influence might affect inhabitants and to protect areas of appropriate acoustic climate. Poland, as a member of European Community is obliged to comply with its law regulations, including the above-cited directive.

The primary legal act that regulates the noise exposure safety issues in Poland is the Environmental Protection Act. According to Article 112, noise exposure protection means providing the most proper condition of acoustic climate by maintaining the level of noise which does not exceed admissible values defined by $L_{D W N}$ and $L_{N}$ indicators [8]. The permissible environmental noise level depends on the nature of its source as well as a purpose of the affected area. The values oscillate in the range between 40-60 $\mathrm{dB}$ (decibel $(\mathrm{dB})$ is a measure of sound pressure level [9]).

NSM consists of a descriptive and graphical part. The first one includes characteristics of an area, acoustic predispositions on the basis of planning documentation of a commune, identification and specification of noise sources as well as diagnosis of endangered areas. The graphical part consists of maps presenting acoustic climate of a study area. They include immission maps, acoustic conflict maps as well as level indicators of inhabitants over normative noise exposure.

According to Art. 7 of Directive 2002/49/EC member states were obliged to compile strategic maps reflecting the situation in the preceding year for all their agglomerations including statements of the period of completion: until June 30, 2007-for agglomerations exceeding 250 thousand inhabitants, until June 30, 2012 — for all the agglomeration within their territory.

In the view of the directive "agglomeration" is defined as a territory with the number of inhabitants over 100 thousand and population density allowing for being recognized as an urban area by a Member State.

In Polish Legal System, this notation is supported by Art. 117 of Environmental Protection Law. According to the article, the diagnosis of the condition of acoustic environment is performed within the national environment monitoring program, on the basis of the results of noise measurement tests for agglomerations of above 100 thousand inhabitants. NSMs have been developed for all the major cities of Poland which exceed 250 thousand inhabitants including: Warsaw, Krakow, Szczecin, Wroclaw, Poznan, Olsztyn or Bydgoszcz. Currently SMAs are being developed for local governments of agglomeration of 100 thousand inhabitants [10].

\section{Apartment Market Analysis Considering Noise Level}

In the present article, it has been stated that participants of local real estate market take into account noise level affecting the neighborhood while making investment decisions such as purchasing an apartment. Verification of this notion will be carried out considering a preselected region of Poland, based 
on a spatial analysis of transaction prices of housing units in relation to an existing noise level defined by NSM.

\subsection{Research Area Characteristics}

The researched market is residential real estate segment of housing units being a subject to real property ownership rights. The research area is located in the city of Bydgoszcz, one of the vastest settlement centers of Poland, located in the northern part of the country. The city is situated on the banks of the Brda River and Bydgoszcz Canal, whose eastern part borders the Vistula River. The research involves several districts: Akademickie-Wschod, Przylesie, Bohaterow and Bajka covering the area of 458 ha (hektar is a unit of measurement of land area) in Fordon, an administrative unit of Bydgoszcz (Fig. 1).

The multi-family residential function is predominant in this area which dates back to one period of history-the 80-ies of 20th century. Service-oriented structures of basic functionality provides complimentary function of the area. Road access is provided by the streets listed in Table 1 .

Noise generated by engine vehicle traffic in the streets creates higher noise zones which significantly affect the surrounding area [11]. The size of the emission, as well as the transgressions, depend on traffic level and in the same time, the following road parameters: type and condition of the surface, number of lanes and their direction, existing traffic lights as well as speed limits for cars and trucks [2].

The period of prices examination included the period of 2009-2010 that is the time following the price correction on the apartment market in Poland, the post-crisis times after which market prices stabilization emerged [4, 12, 13]. It allowed for restraining from making corrections on the basis of price level changes caused by time lapse (time trend equal to 1.0$)$.

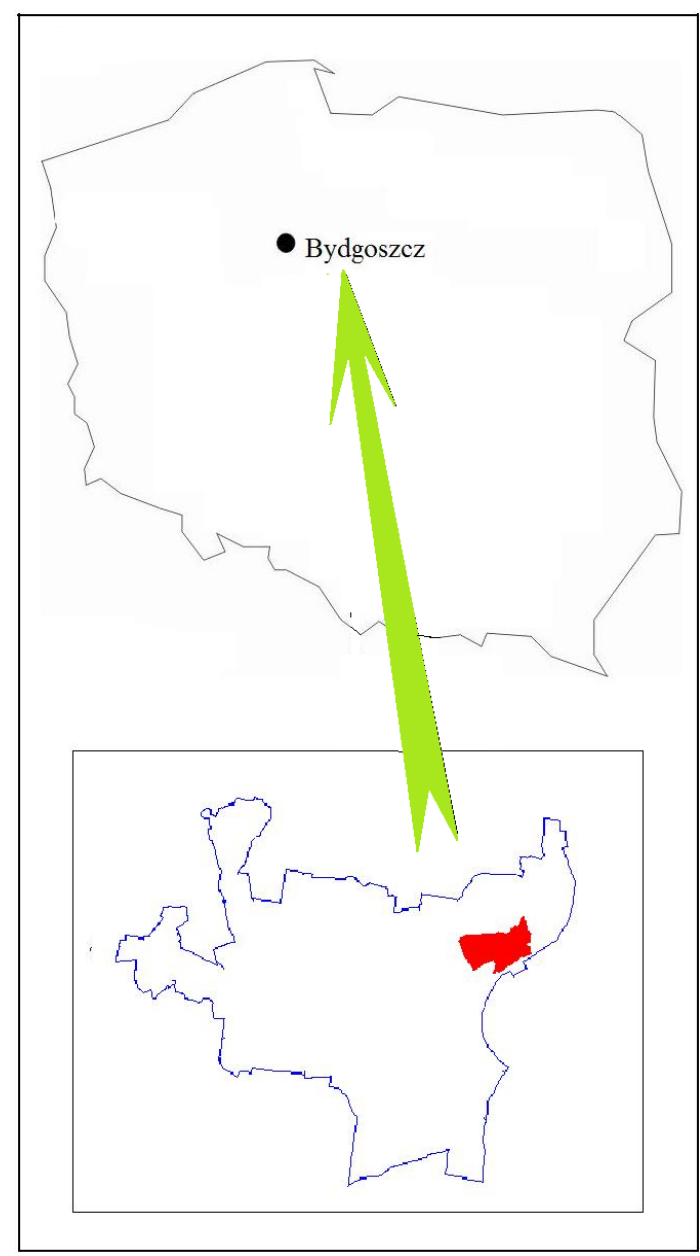

Fig. 1 Polish map of selected cities from the developed SNM.

Table 1 Main streets characteristics in a given area.

\begin{tabular}{|c|c|c|c|c|c|c|}
\hline No. & Street name & Road category & Road type & Surface type & Surface condition $^{*}$ & Speed limit $(\mathrm{km} / \mathrm{h})$ \\
\hline 1 & Fordonska & National & Main & \multirow{9}{*}{$\begin{array}{l}\text { Asphalt of good } \\
\text { condition }\end{array}$} & $\mathrm{a}$ & 80,50 \\
\hline 2 & al. Prof. S. Kaliskiego & Local & Service & & $\mathrm{a}$ & 50 \\
\hline 3 & Akademicka & District & Main & & $\mathrm{b}$ & 50 \\
\hline 4 & Jana Brzechwy & Local & Service & & $\mathrm{m}$ & 50 \\
\hline 5 & gen. Władysława Andersa & District & Main & & $\mathrm{b}$ & 50 \\
\hline 6 & Igrzyskowa & Local & Other & & o & 30 \\
\hline 7 & Christiana Andersena & Local & Other & & $\mathrm{m}$ & 50 \\
\hline 8 & Wojciecha Korfantego Prejsa & Local & Service & & $\mathrm{m}$ & 50 \\
\hline 9 & Jozefa Twardzickiego & Local & Service & & $\mathrm{m}$ & 50 \\
\hline
\end{tabular}

${ }^{*} \mathrm{~m}$-medium, a-alerting, b-bad, o-other. 


\subsection{Market Analysis in Spatial Context}

For the previously defined nature and area of the market as well as the period of prices researching, information of 146 residential unit transactions were gathered. Defined average prices of apartments in the buildings in which the transaction occurred. The study included 45 of the buildings, which accounted for $36.6 \%$ of all residential buildings in the analyzed area. Average prices were placed between $2,541.30 \mathrm{zz} / \mathrm{m}^{2} \div$ $4,110.68 \mathrm{zl} / \mathrm{m}^{2}$ of useable floor area (złoty is the basic unit of currency in Poland). In the subsequent stage, average prices of apartments in the buildings have been grouped according to the following price ranges:

(1) those of average prices placed in the range up to $3,000 \mathrm{zz} / \mathrm{m}^{2}$ of useable floor area;

(2) those of average prices placed in the range from $3,000 \mathrm{z} / / \mathrm{m}^{2}$ to $3,500 \mathrm{z} / \mathrm{m}^{2}$ of useable floor area;

(3) those of average prices placed in the range exceeding $3,500 \mathrm{z} / \mathrm{m}^{2}$ of useable floor area.

The price ranges included apartment transactions of the same general location, same utilities similar transport accessibility, similar technical condition of buildings and the same management system. They varied in size (total floor area ranged from $30.73 \mathrm{~m}^{2}$ to
$78.86 \mathrm{~m}^{2}$ ) finishing standards, floor level as well as detailed location, which as a property feature, includes noise level generated by engine vehicles.

While attempting to find the answer to the question whether noise influences apartment prices, data concerning very similar properties was gathered with the use of ceteris paribus principle (which means unchanged remaining circumstances), and varying only in terms of one feature which is their detailed location, including noise level factor. The technique allows for researching highly complex problems with the sacrifice of some realism [14]. Unfortunately, it was apparently impossible to eliminate every distinguishing feature of the apartments in the course of the study, especially those individual ones concerning the finishing standards, total floor area or floor level. Therefore, it has been assumed that introducing three price ranges including similar properties, only varying in some individual qualities, into the analysis will greatly decrease the influence of these attributes on the value, thus detailed location will remain the only distinguishing feature. Such an analysis policy has been acknowledged right, since the purpose of the research was not the pursuit of the

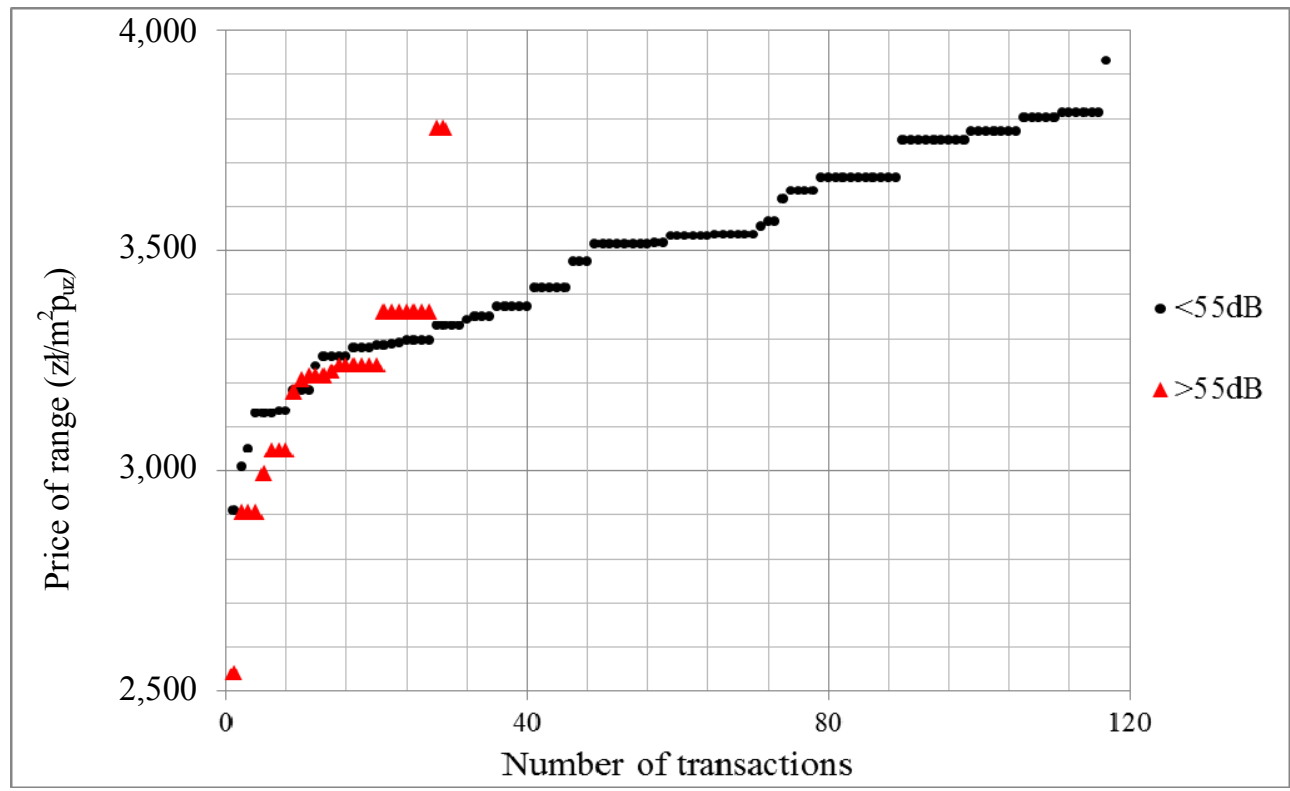

Fig. 2 Prices of single transactions in relation to noise factor of the neighborhood [15]. 
Table 2 Number of transactions in price ranges depending on meeting acoustic standards by resident areas [15].

\begin{tabular}{|c|c|c|c|c|}
\hline \multirow[b]{2}{*}{ No. } & \multirow[b]{2}{*}{ Kind of area } & \multicolumn{3}{|c|}{ Number of transactions in price ranges } \\
\hline & & $\begin{array}{l}\text { Below } 3,000 \mathrm{z} / / \mathrm{m}^{2} \\
\text { useable floor area }\end{array}$ & $\begin{array}{l}3,000 \div 3,500 \mathrm{zz} / \mathrm{m}^{2} \\
\text { useable floor area }\end{array}$ & $\begin{array}{l}\text { Above } 3,500 \mathrm{zz} / \mathrm{m}^{2} \\
\text { useable floor area }\end{array}$ \\
\hline 1 & For the analyzed area & 6 & 68 & 72 \\
\hline 2 & $\begin{array}{l}\text { Residential areas meeting acoustic standards (level } \\
\text { of noise does not exceed } 55 \mathrm{~dB} \text { ) }\end{array}$ & 1 & 47 & 70 \\
\hline 3 & $\begin{array}{l}\text { Residential areas which do not meet acoustic } \\
\text { standards (exceeded levels of noise over } 55 \mathrm{~dB} \text { ) }\end{array}$ & 5 & 21 & 2 \\
\hline
\end{tabular}

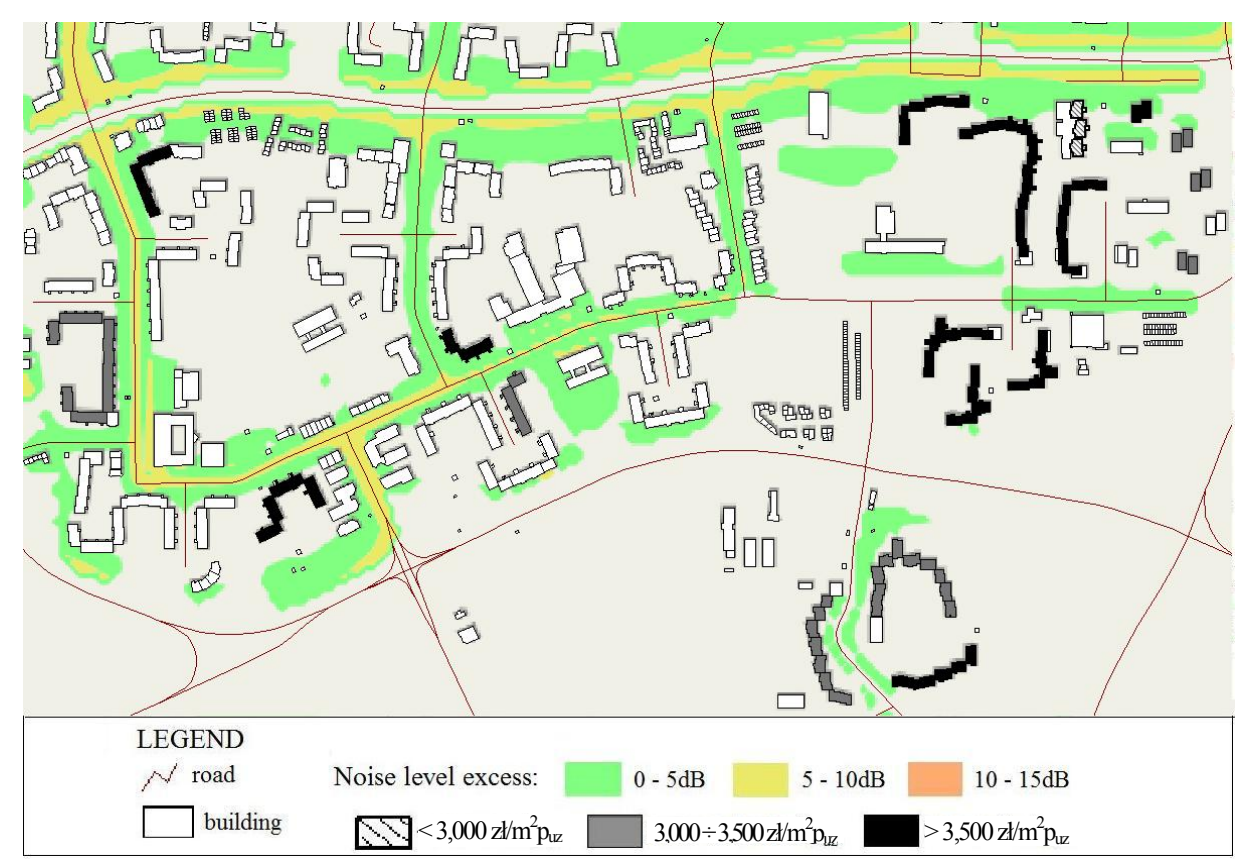

Fig. 3 Spatial location of appartment transactions in relation to a map of excess road traffic noise $L_{D W N}$ (Przylesie, Bohaterow, Akademickie-Wschod districts).

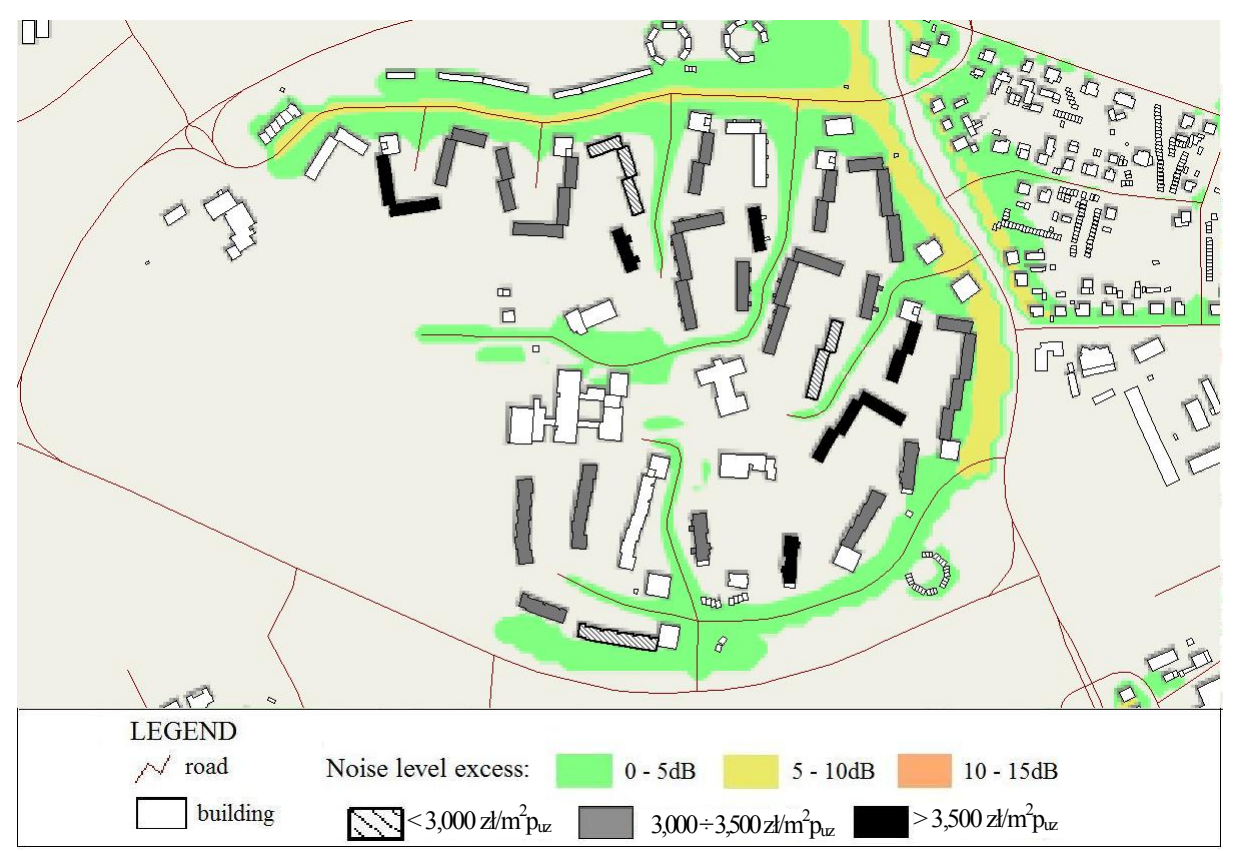

Fig. 4 Spatial location of appartment transactions in relation to a map of excess road traffic noise $L_{D W N}$ (Bajka district). 
importance of noise level as a feature but the question whether, being an environmental condition, it influences the decision making process of market participants.

The number of transactions in single price range has been presented in Fig. 2 and Table 2 and their spatial orientation, with the division into districts in Figs. 3 and 4. The information originating from the real estate marked was presented in relation to an extract of a strategic acoustic map of the city of Bydgoszcz. In Poland for the multi-family housing properties accepted road traffic noise level must not excess $55 \mathrm{~dB}$ [9].

\section{Conclusions}

The analysis allows for drawing the following conclusions:

(1) Acoustic map is certainly a helpful in the analysis and credible source of information concerning noise levels. According to European Union Directive 2002/49/EC, it is available in numerous Polish agglomeration or it will appear in a near future;

(2) Most of multi-family residential buildings in the area of the study in Poland - the districts of Fordon in the city of Bydgoszcz is located outside the zone of excessive traffic noise levels;

(3) Out of 118 market transactions concerning sales of apartments located in buildings of acceptable noise level areas, most of them $(60 \%)$ originated from the range of the highest price values: $>3,500 \mathrm{zt} / \mathrm{m}^{2}$ of useable floor area and only 1 transaction from the lowest value range below $3,000 \mathrm{z} z / \mathrm{m}^{2}$ of useable floor area. The remaining, approximately $30 \%$, came from the range of $3,000 \div 3,500 \mathrm{zt} / \mathrm{m}^{2}$ of total floor area;

(4) Out of 28 transactions of apartments situated in buildings of excessive noise level, a majority of them (75\%) obtained lower price level of $3,000 \div 3,500$ $\mathrm{z} / \mathrm{m} \mathrm{m}^{2}$ of total floor area and $18 \%$ of those-the lowest-below $3,000 \mathrm{z} / / \mathrm{m}^{2}$ of total floor area. Only two of them obtained the highest level;
(5) Preliminary research results have shown that real estate market participants take unfavorable acoustic climate of the surrounding area into consideration while purchasing residential properties, which results in lower price of a given apartment;

(6) Unfavorable environment interaction such as noise is reflected in lower market prices paid for residential properties located in areas of excessive noise level.

The preliminary results can be further validated using statistical methods such as multiple regression analysis [16].

\section{References}

[1] J. Kwiecień, K. Szopińska, Implementation of the EU noise directive in process of urban planning in Poland, international archives of the photogrammetry, remote sensing and spatial information sciences, in: 29th Urban Data Management Symposium, London, United Kingdom, May 29-31, 2013.

[2] J. Kwiecień, K. Szopińska, M. Sztubecka, Problem of noise protection in urban areas on the example of Bydgoszcz, Ecology and Technology 18 (4) (2010) 205-212.

[3] M. Krajewska, Planning conditions and the market value of real estate, in: E. Siemińska (Ed.), Investment on the Real Estate Market, Scientific Publisher of Nicolaus Copernicus University, Toruń, 2011, pp. 63-99.

[4] Analysis of the Housing Market, 2011, http://www.rp.pl/temat/230927.html (assessed Sep. 1, 2012).

[5] Appraisal Institute, The Appraisal of Real Estate, 11th ed., Chicago, Illinois, 1996.

[6] L. Nykiel, The functions and role of the state in the housing market, Journal of the Polish Real Estate Scientific Society 18 (3) (2010) 7-21.

[7] M. Rymarzak, Housing Market in Selected EU Countries, Real Estate-Valuation, Profitability and Risk, Papers and Reports of the Faculty of Management of Gdansk University, Sopot, 2000, pp. 167-174.

[8] M. Krajewska, K. Szopińska, The acoustic map as a source of information about the real estates, World of Real Estate 76 (2011) 29-33.

[9] Z. Engel, Environmental Protection against Vibration and Noise, Polish Scientific Publishers PWN, Poland, 2001.

[10] Noise Map of City of Bydgoszcz, Bydgoszcz, 2008, http://mapy.bydgoszcz.pl/bydgoszcz/index.php/en/ (assessed Sep. 1, 2012). 
[11] C. Asensio, J. López, R. Pagán, I. Pavón, M. Ausejo, GPS-based speed collection method for road traffic noise mapping, Transportation Res. Part D: Transport and Environment 14 (5) (2009) 360-366.

[12] E. Siemińska, Residential buildings developers functioning in Poland after the crisis, Journal of the Polish Real Estate Scientific Society 18 (3) (2010) 29.

[13] E. Siemińska, Banks' practical experience in shaping credit policies for financing the real estate market, in: E. Siemińska (Ed.), Investment on the Real Estate Market, Scientific Publisher of Nicolaus Copernicus University,
Toruń, 2011, pp. 32-42.

[14] E. Kucharska-Stasiak, Back to the sources-Discussion about the market value, Valuer 67 (2010) 16-22.

[15] M. Krajewska, K. Szopińska, The acoustic climate as a factor affecting the market value of real estate of housing, in: 3rd International Seminar on Urban Investments, Cracow, 2011, pp. 447-455.

[16] R. Cellmer, Spatial analysis of the effect of noise on the prices and value of residential real estates, Geomatics and Environmental Engineering Selected Full Texts 5 (4) (2011) 13-28. 